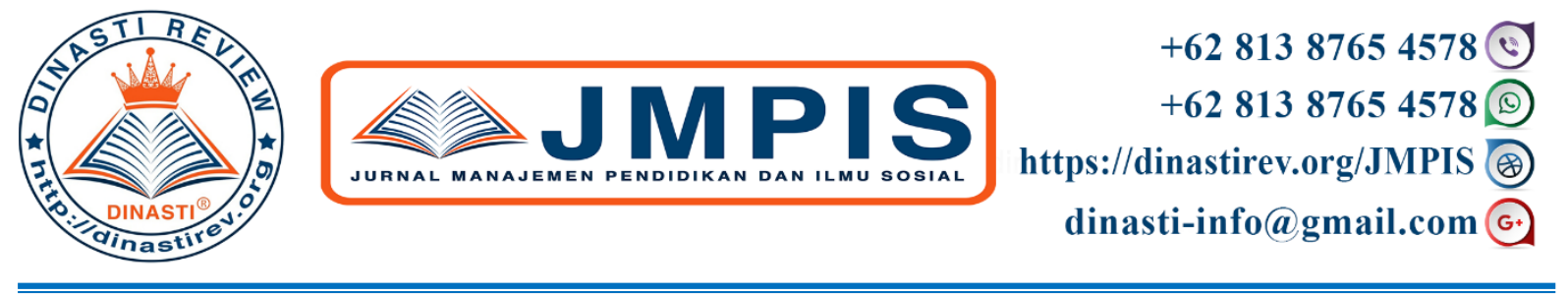

\title{
PENGARUH KONTEN PEMASARAN SHOPEE TERHADAP KEPUTUSAN PEMBELIAN PELANGGAN
}

\author{
Ramayani Yusuf ${ }^{1}$, Heny Hendrayati ${ }^{2}$, Lili Adi Wibowo ${ }^{3}$ \\ 1) Universitas Pendidikan Indonesia, Bandung, Indonesia \\ 2) Universitas Pendidikan Indonesia, Bandung, Indonesia \\ 3) Universitas Pendidikan Indonesia ,Bandung, Indonesia
}

\begin{tabular}{|c|c|}
\hline $\begin{array}{c}\text { ARTICLE INFORMATION } \\
\text { Received: } 10 \text { April } 2020 \\
\text { Revised: } 15 \text { Mei } 2020 \\
\text { Issued: } 18 \text { Juli } 2020 \\
\text { Corresponding author: first author } \\
\text { E-mail: } \\
\text { ramayani_rahman@yahoo.com }\end{array}$ & $\begin{array}{l}\text { Abstract:Penelitian ini bertujuan mengetahui konten Shopee } \\
\text { terhadap keputusan pembelian customer. Penelitian ini } \\
\text { menggunakan jenis penelitian deskriptif dengan pendekatan } \\
\text { kuantitatif. Variabel yang digunakan dalam penelitian ini ada } \\
\text { lima, yaitu Design (X1),berita terkini(X2), pengalaman } \\
\text { menarik saat membaca(X3), waktu penayangan(X4) dan } \\
\text { kesesuaian berita (X5). Pengumpulan data diperoleh melalui } \\
\text { penyebaran kuesioner secara online (e-kuesioner) pada } \\
\text { Mahasiswa Jurusan Manajemen Bisnis Politeknik Piksi } \\
\text { Ganesha yang pernah menggunakan aplikasi Shopee. Sampel } \\
\text { yang digunakan dalam penelitian ini berjumlah 170 orang } \\
\text { responden. Teknik pengambilan sampel yang digunakan } \\
\text { adalah purposive sampling. Analisis data yang digunakan } \\
\text { adalah analisis deskriptif dan analisis regresi linier berganda. } \\
\text { Hasil penelitian menunjukkan bahwa variabel design } \\
\text { (X1),berita terkini (X2), pengalaman saat membaca (X3), } \\
\text { waktu penayangan (X4), kesesuaian berita (X5) secara } \\
\text { bersama-bersama berpengaruh secara simultan dan } \\
\text { signifikan terhadap Struktur Keputusan Pembelian (Y). Hasil } \\
\text { Uji Simultan atau Bersama-sama (Uji F) menunjukkan } \\
\text { bahwa berpengaruh signifikan terhadap variabel terikat } \\
\text { yaiitu Struktur Keputusan Pembelian (Y). Hal ini terbukti } \\
\text { dari hasil nilai sig. F (0,018) < sig. } \alpha \text { (0,05) dan hasil } \\
\text { koefisien determinasi (Adjusted } \mathrm{R} \text { Square) sebesar 0,281 } \\
\text { atau setara dengan 28,1 \% yang artinya variabel bebas dapat } \\
\text { memengaruhi variabel terikat sebesar 28,1 \% sedangkan } \\
71,9 \% \text { sisanya dipengaruhi oleh variabel-variabel lain yang } \\
\text { tidak dibahas dalam penelitian ini. Berdasarkan hasil } \\
\text { penelitian ini, sebaiknya Shopee melakukan inovasi konten } \\
\text { yang telah dilakukan untuk semakin memperkuat keputusan } \\
\text { pembelian produk. } \\
\text { Keywords: Konten Pemasaran, Keputusan Pembelian }\end{array}$ \\
\hline
\end{tabular}




\section{INTRODUCTION}

Revolusi Industri 4.0 merupakan hal yang tidak dapat dihindari dan merupakan bagian dari perubahan global. Saat ini dengan mudah kita dapat mengakses berbagai macam informasi dengan menggunakan internet. Internet membuka wawasan dan keterbukaan informasi bagi semua orang.

\begin{tabular}{lr}
\hline Digital Indonesia- Jan. 2019 \\
\hline Population & $268.2 \mathrm{M}$ \\
Mobile subscriptions & $355.5 \mathrm{M}$ \\
Internet users & $150.0 \mathrm{M}$ \\
Social media users & $150.0 \mathrm{M}$ \\
Mobile social users & $130.0 \mathrm{M}$
\end{tabular}

\section{Gambar 1. Data Pengguna Internet}

Sumber : Asean Up, 2019

Pengguna Internet di Indonesia memasuki angka 150 juta , berarti 55,9\% masyarakat Indonesia menggunakan layanan ini untuk berbagai keperluan. Kemudahan - kemudahan yang didapat dari internet ini juga merubah gaya hidup dan menggeser kebiasaankebiasaan di masyarakat. Fungsi pasar yang biasanya harus bertemu antara pembeli dan penjual, bergeser cukup dengan menggunakan aplikasi jual beli yang marak saat ini. Pengguna Internet yang banyak ini menimbulkan peluang baru bagi perusahaan untuk tetap memanfaatkan internet sebagai media untuk perdagangan dan promosi yang dikenal luas sebagai Pemasaran Digital. Sebagai alat yang digunakan dalam Pemasaran Digital biasanya situs web perusahaan, perusahaan, membuat blog perusahaan, atau menjual barang melalui media sosial seperti Facebook, Instagram, Path, dan Twitter. (Asean Up 2019)

Pemasaran Digital ini merupakan salah satu strategi untuk mempromosikan produk mereka. Tidak hanya pembeli yang menjadi potensi pasar, tetapi para penjual ini juga bersaing melalui produk mereka konten yang mereka terbitkan. Beramai- ramai penjual memberikan sesuatu yang berbeda, menarik, dan edukatif kepada konsumen agar dapat memikat dan menimbulkan minat beli. Usaha para penjual / produsen memciptakan minat beli memberikan istilah konten pemasaran ( content marketing ). Konten Pemasaran ( content marketing ) sekarang banyak dibahas dan menjadi fokus utama dari para penjual dan produsen yang bermain di digital marketing. Mereka berlomba- lomba menciptakan konten yang menarik dan semakin dekat dengan konsumen mereka. Konten pemasaran ini harus dapat memikat dan menggiring para pengguna digital untuk melihat, memperhatikan dan pada akhirnya melakukan pembelian pada produk mereka. (Astari, 2017)

Saat ini terdapat beberapa e commerce yang bersaing, dan merebutkan konsumen untuk dapat mengunjungi, melihat dan membeli pada situs mereka. Beberapa e commerce bersaing ingin merebut konsumen di Indonesia, dari data yang diperoleh terdapat 




Gambar 2. Peringkat e-commerce

Peringkat pertama diduduki oleh Tokopedia disusul Bukalapak, Shopee , Lazada, Blibli, JD Id, Orami dan Sociolla. Rata-rata kunjungan web bulanan e-commerce lokal Tokopedia dan Bukalapak terbesar di Indonesia. Tokopedia berada di peringkat pertama versi data jumlah pengunjung bulanan website terbanyak dengan rataan 137.200.900 kunjungan per bulan. Startup dengan status Unicorn ini naik satu peringkat dibanding kuartal yang sama tahun 2018. Pada Q1 tahun lalu, jumlah pengunjung bulanan Tokopedia sebanyak 117,297,000. Sedangkan Bukalapak menempati posisi kedua dengan jumla pengunjung bulanan 115,256,600. Sama seperti Tokopedia, Bukalapak juga naik satu peringakt dibanding Q1 tahun lalu. Kunjungan bulanan untuk web e-commerce dengan produk spesifik meningkat. Shopee menduduki peringkat ketiga dengan jumlah pengunjung 74.995.300 ( Asean Up 2019)

Penelitian terdahulu :

- Content marketing berpengaruh pada Customer Engagement melalui viral marketing sebagai moderasu pada pengguna Tokopedia di Yogyakarta

- Content marketing berpengaruh pada pembentukan brand awareness dan membentuk keputusan pembelian pada Kalbis Institute

Penulis tertarik dengan naiknya Shopee menjadi e Commerce dengan pengunjung dan berhasil menjaring begitu banyak konsumen mengunjungi situs mereka dan melakukan pembelian. Dari paparan diatas, mengenai konten pemasaran , penulis tertarik untuk meneliti "PENGARUH KONTEN PEMASARAN SHOPEE TERHADAP KEPUTUSAN PEMBELIAN PELANGGAN"

\section{LITERATURE REVIEW}

\section{Konten Pemasaran}

Perkembangan internet selama satu dekade terakhir ini telah memberi celah baru bagi para pemasar dalam menjalankan komunikasi pemasaran. Jumlah pengguna yang meningkat dari tahun ke tahun menjadikan internet menjadi media yang potensial sebagai media kkomunikasi pemasaran. Selain itu, kemampuan internet untuk dapat menyampaikan pesan dengan cepat dan luas menjadi alasan lain bagi para pemasar untuk menggunakannya sebagai media pemasaran. Para pemasar yang hendak menjalankan komunikasi pemasaran melalui internet hendaknya mengetahui juga karakteristik yang dimiliki oleh internet.

Di pihak lain Pulizzi (2014:5) mendefinisikan content marketing sebagai "The marketing and business process for creating and distributing valuable and compelling content to attract, acquire, and engage a clearly defined and understood target audience with the objective of driving profitable customer action.". Content marketing didefinisikan sebagai proses pemasaran dan bisnis untuk membuat dan mendistribusikan konten yang berharga dan menarik untuk mengajak, memperoleh, dan melibatkan sasaran audiensi yang jelas dengan tujuan mendorong tindakan customer yang menguntungkan. Mathey

Karakteristik yang dimiliki internet telah membuat internet menjadi media yang unik dan berbeda dengan media konvensional. Pelaku pemasaran pun dituntut untuk mengubah pola pikir pemasarannya. Media baru telah menghadirkan interaktivitas yang mendorong 
adanya komunikasi dua arah yang bersifat lebih personal antara pemasar dengan targetnya. Oleh karena itu, komunikasi yang bersifat dialog lebih dikembangkan sebagai proses komunikasi antara pemasar dengan targetnya. Berbeda dengan komunikasi pemasaran di media konvensional yang komunikasinya masih bersifat monolog. Komunikasi pemasaran dengan memanfaatkan media baru merupakan proses untuk membentuk kesempatan bagi setiap pengguna untuk terhubung, berbagi, membentuk, membentuk lagi (co-create), mendistribusikan, dan menyadari suatu brand. Dengan kata lain, media baru telah membuka peluang bagi pemasar untuk meningkatkan interaktivitas antara brand dengan konsumennya.

Konten dalam konsep pemasaran bisa dalam berbagai bentuk. Seperti yang barusan disebutkan: gambar, video, audio, tulisan, dsb. Selain bentuknya, kita juga bisa membedakan konten dari sifatnya: menghibur, mendidik, emosional, dll. Tetapi yang terpenting adalah, konten harus menarik. Kalau konten tidak mampu membuat orang lain tertarik untuk menyimak, berarti perusahaan tersebut telah gagal dalam upaya content marketing.

Menurut McPheat (2011: 10) mendefinisikan content marketing sebagai:

"Content marketing is defined as publishing content that empowers, engages, educates, and connects readers".

Pendapat pakar Riverside Marketing Strategies, Heidi Cohen (2013), content marketing yaitu memberikan informasi kepada konsumen untuk membantu memutuskan membeli sebuah produk, meningkatkan nilai lebih pada penggunaan sebuah produk, dan memberikan hiburan tanpa mengesampingkan pencapaian tujuan perusahaan melalui cara promosi yang tidak mencolok.

Dalam buku Content Marketing oleh Rebecca Lieb, content marketing adalah strategi pemasaran dengan cara menghasilkan konten yang bertujuan untuk memberi informasi kepada target (konsumen) yang bersifat persuasi, atas produk yang dipasarkan. Persuasi adalah ajakan dengan cara memberikan alasan dan prospek yang baik untuk meyakinkan. Pendekatan strategi pemasaran ini difokuskan pada pembuatan dan pendistribusian konten yang bernilai, relevan dan konsisten agar bisa menarik dan mempertahankan audiens yang sudah ditetapkan secara jelas, dan secara keseluruhan untuk mendorong tindakan pelanggan yang bisa menghasilkan keuntungan.

Dengan demikian fungsi dan tujuan content marketing adalah untuk mengedukasi konsumen dan menjadi jembatan yang menghubungkan antara produsen dan konsumen untuk membentuk sebuah proses komunikasi yang menyenangkan melalui informasi- informasi dari konten yang dimiliki. Artinya, pemasaran konten bukan sebagai strategi memasarkan produk atau jasa secara langsung melainkan usaha penciptaan konten yang bertujuan untuk mempengaruhi konsumen untuk melakukan pembelian, atau konten yang dipasarkan akan mempengaruhi konsumen pada keputusan pembelian. Penggunaan strategi content marketing memiliki tujuan untuk menarik dan mempertahankan pelanggan dengan cara konsisten membuat dan mengurasi konten-konten bernilai dan relevan

Dalam menciptakan content marketing yang menarik dan kreatif, diperlukan beberapa faktor yang harus diperhatikan, yaitu sebagai berikut:

1) Design

Pengguna internet saat ini cerdas, khalayak telah mengunjungi beberapa situs web, mengetahui seperti apa desain yang bagus . Selain itu, kategori konten yang berbeda digambarkan oleh warna, membantu membagi lebih jauh konten ke dalam kelompok yang berbeda. Konten yang menarik tidak akan berpengaruh besar apabila tidak diseimbangkan dengan desain yang dibuat. Tata letak tipografi membantu untuk memandu perhatian khalayak dengan sedikit dorongan atau petunjuk tambahan. Desain background, pemilihan warna dan tata letak (layout) yang baik akhirnya menimbulkan respons psikologis yang sepadan dengan topik yang dibahas. Warna dan desain juga berbicara tentang merek

2) Current Event Konten yang baik adalah konten yang menyajikan berita-berita seputar kejadian dan 
fenomena yang saat ini sedang berlangsung. Dengan demikian, konten yang dibuat akan terbaca oleh Google dan memungkinkan pengguna internet untuk mengunjungi situs maupun media sosial yang kita miliki

3) The Reading Experience

Desain yang menarik tidak hanya tentang warna-warna dan gambar yang eye catchy, tetapi juga bagaimana tata letak dan font yang digunakan agar konten pun tetap terbaca dengan baik dan effortless.

4) Timing

Setelah mengemas konten dengan menarik dengan desain yang menarik dan mudah dibaca, langkah selanjutnya yang harus diperhatikan adalah kapan dan berapa kali konten tersebut diunggah. Dalam membangun sebuah kesadaran merek kepada khalayak melalui penggunaan media sosial, perlu adanya intensitas dan frekuensi yang konsisten dalam mengunggah sebuah konten, karena tidak semua orang langsung melihat konten yang baru saja diunggah.

5) Tone

Kesesuaian berita mempengaruhi pada keputusan pembelian pelanggan.

\section{Keputusan Pembelian}

Menurut Boyd Walker pengambilan keputusan pembelian merupakan sebuah pendekatan penyelesaan masalah pada kegiatan manusia membeli suatu produk guna memenuhikeinginan dan kebutuhan. Perilaku konsumen menjadi hal-hal yang mendasari konsumen untuk membuat keputusan pembelian. Adapun hal- hal tersebut adalah proses dan aktivitas ketika seseorang (konsumen) berhubungan dengan pencarian, pemilihan, pembelian, penggunaan, serta pengevaluasian produk dan jasa demi memenuhi kebutuhan dan keinginan.

Menurut Swastha dan Irawan (2008:118) keputusan pembelian adalah pemahaman konsumen tentang keinginan dan kebutuhan akan suatu produk dengan menilai dari sumber-sumber yang ada dengan menetapkan tujuan pembelian serta mengidentifikasi alternatif sehingga pengambil keputusan untuk membeli yang disertai dengan perilaku setelah melakukan pembelian.

Sedangkan Irawan dan Farid (2000:41) mengemukakan keputusan pembelian adalah tahap penilaian keputusan yang menyebabkan pembeli membentuk pilihan di antara beberapa merek yang tergabung dalam perangkat pilihan dan membentuk maksud untuk membeli. Perilaku konsumen akan menentukan pengambilan keputusan dalam pembelian mereka. Proses tersebut merupakan sebuah pendekatan penyelesaian masalah yang terdiri atas enam tahap yaitu: menganalisa keinginan dan kebutuhan, menilai beberapa sumber yang ada, menetapkan tujuan pembelian, mengidentifikasikan alternatif pembelian, mengambil keputusan untuk membeli dan perilaku sesudah pembelian.

Menurut Sangadji dan Sopiah (2013:119) Keputusan merupakan hasil proses pemikiran yang berupa pemilihan satu diantara beberapa alternatif pilihan yang dapat digunakan untuk memecahkan masalah yang dihadapinya.

Tahap-tahap Proses Keputusan Pembelian Menurut Kotler dan Keller, ada lima tahap yang dilalui oleh konsumen dalam membuat keputusan pembelian, yaitu:

a. Pengenalan masalah Proses pembelian dimulai dari pembeli mengenali masalah atau kebutuhan konsumen .

b. Pencarian Informasi Konsumen akan terdorong untuk mencari informasi yang lebih banyak untuk mengetahui kebutuhannya.

c. Evaluasi Alternatif Konsumen mengolah informasi dari berbagai merek yang bersaing dan membuat penilaian akhir tentang kebutuhan kebutuhan yang akan dibeli.

d. Keputusan Pembelian Setelah tahap evaluasi, konsumen membuat daftar tabel atas merek-merek yang ada di dalam pilihannya. Konsumen juga membuat keputusan akhir untuk membeli merek yang paling disukai untuk memenuhi kebutuhannya. 
e. Perilaku Pasca Pembelian Setelah pembelian, apabila konsumen merasa senang dan puas akan barang atau merek tersebut, biasanya mereka akan kembali memesan barang lainnya untuk memenuhi kebutuhannya.

\section{RESEARCH METHODS}

Objek penelitian ini adalah e Commerce Shopee, merupakan platform perdagangan elektronik yang berkantor pusat di Singapura di bawah SEA Group (sebelumnya dikenal sebagai Garena), yang didirikan pada 2009 oleh Forrest Li. Shopee pertama kali diluncurkan di Singapura pada tahun 2015, dan sejak itu memperluas jangkauannya ke Malaysia, Thailand, Taiwan, Indonesia, Vietnam, dan Filipina. Karena elemen mobile yang dibangun sesuai konsep perdagangan elektronik global, Shopee menjadi salah satu dari "5 startup e-commerce yang paling disruptif" yang diterbitkan oleh Tech In Asia

a. Sejarah

Pada tahun 2015, Shopee pertama kali diluncurkan di Singapura sebagai pasar mobilesentris sosial pertama dimana pengguna dapat menjelajahi, berbelanja, dan menjual kapan saja terintegrasi dengan dukungan logistik dan pembayaran yang bertujuan untuk membuat belanja online mudah dan aman bagi penjual dan pembeli.

Setelah itu Shopee yang berpusat di Singapura, melakukan ekspansi ke negara ASEAN lain dan membuka Shopee Indonesia, Shopee Malaysia, Shopee Thailand, Shopee Taiwan, Shopee Vietnam dan Shopee Filipina

b. Model Bisnis

Shopee pertama kali dimulai sebagai pasar pelanggan untuk pelanggan (C2C) tetapi telah beralih ke model hibrid $\mathrm{C} 2 \mathrm{C}$ dan Bisnis untuk Pelanggan (B2C) semenjak meluncurkan Shopee Mall yang merupakan platform toko daring untuk distribusi brand ternama.

c. Pangsa Pasar

Pada tahun 2017, platform ini mencatat 80 juta unduhan aplikasi dan lebih dari 180 juta produk aktif dari lebih dari empat juta wirausaha. Pada Q4 2017, melaporkan nilai perdagangan bruto (GMV) sebesar US \$ 1,6 miliar, naik 206 persen dari tahun sebelumnya

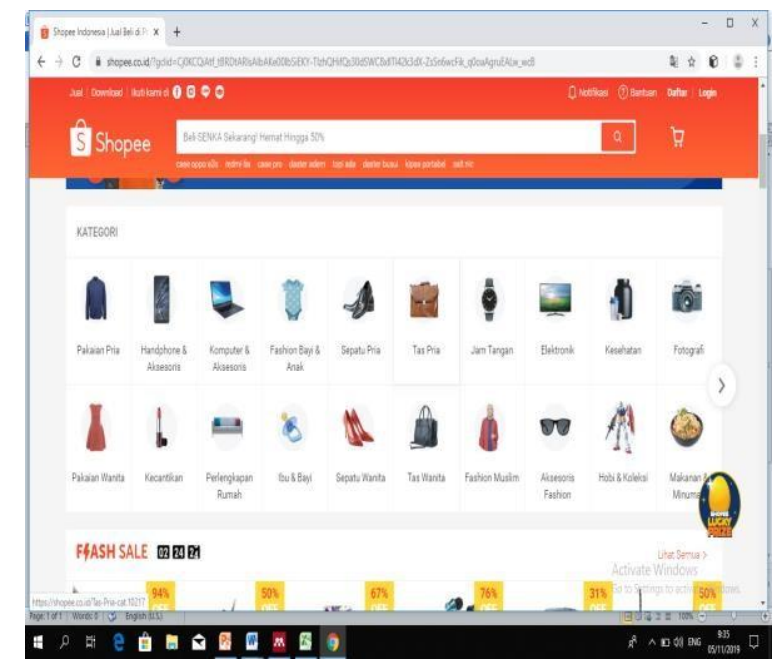

Gambar 3 : Tampilan Shopee

\section{METODELOGI PENELITIAN}

Penelitian ini merupakan penelitian deskriptif dengan pendekatan kuantitatif. Penelitian dilakukan di Program Studi Manajemen Bisnis Politeknik Piksi Ganesha Bandung. Pemilihan lokasi ini dilakukan karena mahasiswa Program Studi Manajemen Bisnis Politeknik Piksi Ganesha menggunakan aplikasi Shopee. Didapat sampel 170 
orang responden dengan pengumpulan data menggunakan kuesioner yang dianalisis menggunakan regresi linier.

\section{FINDINGS AND DISCUSSION}

\section{Uji Validitas}

Digunakan untuk mengukur valid atau tidaknya instrument yang kita gunakan.

Table 1.Hasil Uji Validitas

\begin{tabular}{|l|l|l|l|l|}
\hline Model & R hitung & R table & Sig. & Keterangan \\
\hline X1 & 0,793 & 0,674 & 0.000 & Valid \\
\hline X2 & 0,738 & 0,674 & 0.000 & Valid \\
\hline X3 & 0,721 & 0,674 & 0.000 & Valid \\
\hline X4 & 0,715 & 0,674 & 0.000 & Valid \\
\hline X5 & 0,729 & 0,674 & 0.000 & Valid \\
\hline
\end{tabular}

Sumber : Data primer yang diolah

Berdasarkan hasil R hitung dimana semua lebih besar dari R nilai , dapat dipastikan semua item valid untuk lanjut diteliti.

\section{Uji regresi linear sederhana}

Analisis regresi sederhana digunakan untuk mengetahui apakah ada pengaruh dari variabel bebas atau independen terhadap variabel terikat atau dependen. Dalam penelitian ini, yang akan menjadi variabel terikat adalah content marketing dan yang menjadi variabel bebas adalah keputusan pembelian. Untuk menguji apakah terdapat pengaruh antara content marketing terhadap keputusan pembelian Shopee, maka digunakan hipotesis sebagai berikut: H0: Tidak terdapat pengaruh antara content marketing terhadap keputusan pembelian Shopee Ha: Terdapat pengaruh antara content marketing terhadap keputusan pembelian Shopee

Table 2 Hasil Uji Regresi Linier Sederhana

\begin{tabular}{|c|c|c|c|c|c|}
\hline \multicolumn{6}{|c|}{ ANOVA $^{a}$} \\
\hline Model & $\begin{array}{l}\text { Sum of } \\
\text { Squares }\end{array}$ & Df & $\begin{array}{l}\text { Mean } \\
\text { Square }\end{array}$ & $\mathrm{F}$ & Sig. \\
\hline $\begin{array}{ll}1 & \text { Regressio } \\
\mathrm{n}\end{array}$ & 21.978 & 5 & 4.396 & 2.808 & $.018^{\mathrm{b}}$ \\
\hline Residual & 256.727 & 164 & 1.565 & & \\
\hline Total & 278.706 & 169 & & & \\
\hline
\end{tabular}

a. Dependent Variable: y

b. Predictors: (Constant), x5, x4, x1, x3, x2

Berdasarkan analisis regresi yang telah dilakukan melalui SPSS 24, diperoleh hasil nilai signifikansi sebesar 0.018 atau nilai kurang dari 0.05 . Dengan demikian, dapat disimpulkan bahwa H0 ditolak dan Ha diterima. Artinya, terdapat pengaruh antara content marketing Shopee terhadap keputusan pembelian. Content Marketing yang diterapkan oleh Shopee memberikan pengaruh terhadap keputusan pembelian .

\section{Uji Realibilitas}

Suatu variabel dikatakan reliabel jika memberikan nilai Cronbach Alpa> 0,60

\section{Table 3. Hasil Uji Realibitas}

\section{Reliability Statistics}

Cronbach's Alpha $\mathrm{N}$ of Items

$.797 \quad 3$


Hasil Cronbach's Alpha table diatas menunjukkan bahwa pada pengujian ini dilakukan secara variabel bukan secara item pertanyaan pada setiap variabel yang dapat dilihat hasilnya adalah nilai cronbah's alpha lebih besar daripada 0,6 maka dapat dikatakan reliebel.

\section{Uji Asumsi Klasik}

Pengujian ini dilakukan untuk melihat data yang digunakan mengalami penyimpangan asumsi klasik atau tidak.Pada uji asumsi yang dilakukan tedapat 3 uji yang digunakan yaitu uji normalitas, uji multikolinieritas, dan uji heteroskedastisitas. Hasil dari 3 uji yang digunakan adalah: a. Uji Normalitas Uji normalitas digunakan untuk menguji apakah dalam model regresi, variabel pengganggu atau residual memiliki distribusi yang normal. Metode uji normalitas yang dapat digunakan untuk menguji normalitas residual adalah kolmogorov-Sminov (KS)

Table 4. Hasil Tes Kolmogorov - Smirnov

One-Sample Kolmogorov-Smirnov Test

\begin{tabular}{|c|c|c|}
\hline & & Unstandardized Predicted Value \\
\hline$\overline{\mathrm{N}}$ & & (l) \\
\hline Normal Parameters ${ }^{\mathrm{a}, \mathrm{b}}$ & Mean & 3.1764706 \\
\hline & $\begin{array}{l}\text { Std. } \\
\text { Deviation }\end{array}$ & .36062447 \\
\hline Most Extreme & Absolute & .065 \\
\hline Differences & Positive & .057 \\
\hline & Negative & -.065 \\
\hline Test Statistic & & .065 \\
\hline Asymp. Sig. (2-tailed) & & $.079^{\mathrm{c}}$ \\
\hline
\end{tabular}

Berdasarkan table diatas menunjukkan bahwa nilai yang dihasilkan pada Äsym.sig sebesar 0,079 yang dapat dikatakan nilai asymp.sig 0,079 lebih besar daripada 0,05 maka dapat dikatakan data berditribusi normal.

Table 5. Hasil Uji Multikolinearitas

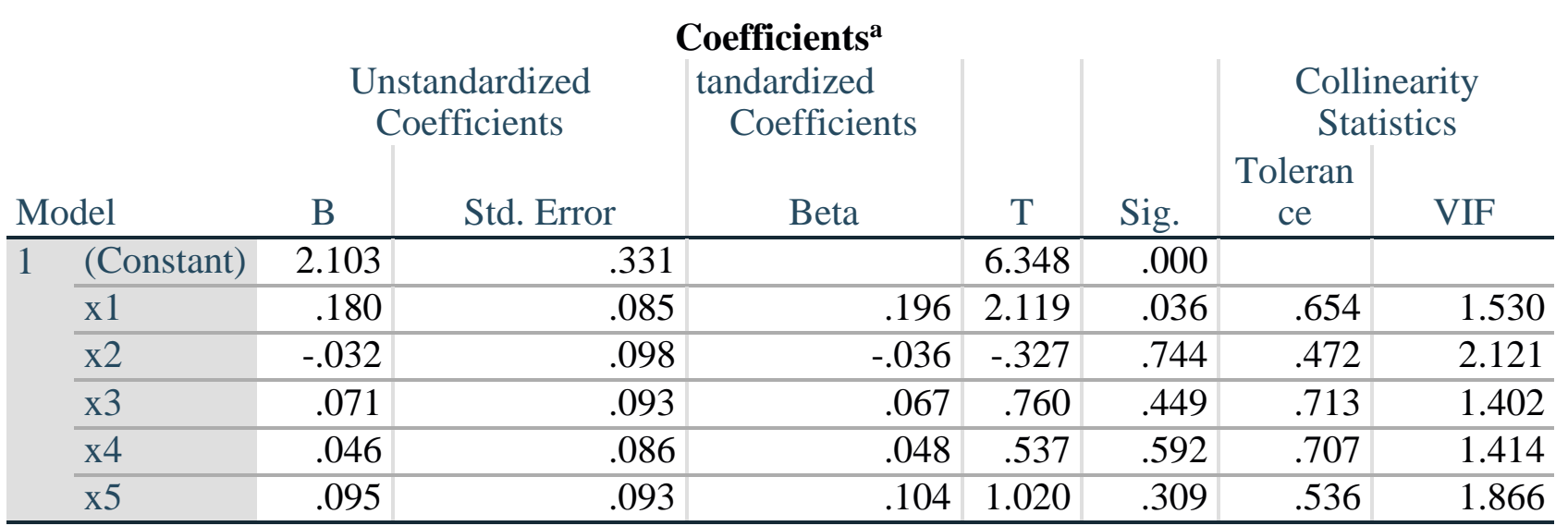

a. Dependent Variable: y

Dari hasil perhitungan yang ada pada table hasil uji multikolinearitas, variable bebas menunjukkan bahwa nilai VIF adalah 1,$530 ; 2,121 ; 1,402 ; 1,414$; dan 1,866 dimana nilai tersebut lebih kecil dari 10, shingga dapat disimpulkan bebas dari multikolinearitas 


\section{Uji T}

\section{Table 6. Hasil Uji T}

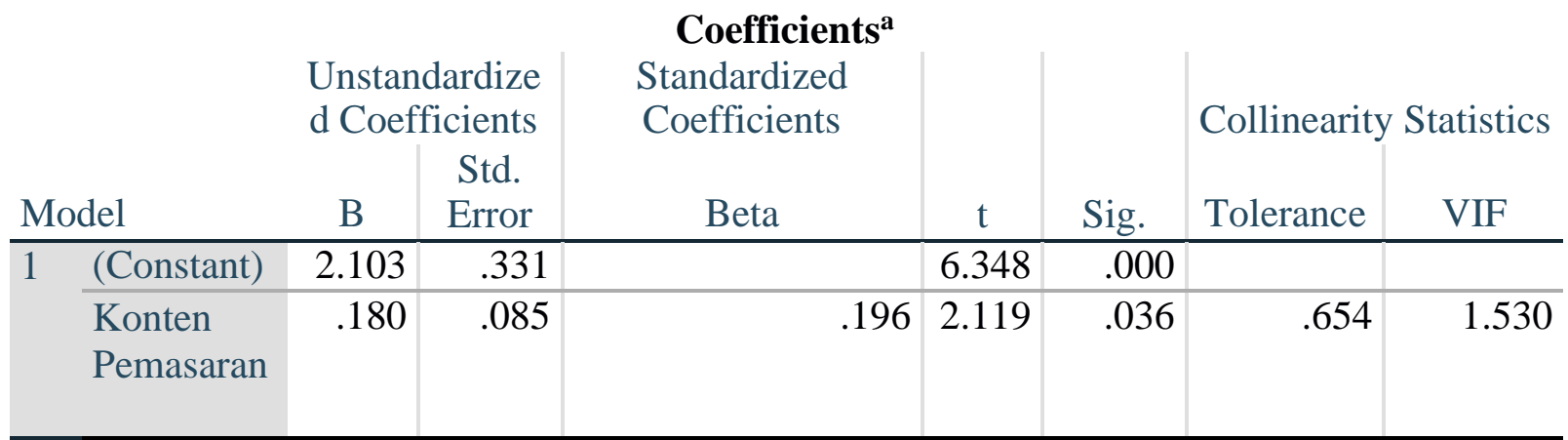

a. Dependent Variable: y

Hasil analisis regresi menyatakan bahwa variabel bebas berpengaruh terhadap variabel terikat. Untuk itu analisis regresi yang dilakukan juga menghasilkan sebuah model regresi yaitu sebagai berikut :

\section{Koefisien Determinan}

$$
\boldsymbol{Y}=2,103+\mathbf{0} .180 \mathrm{x}
$$

Table 6. Hasil Perhitungan Koefisien Determinan Model Summary
\begin{tabular}{|l|l|r|r|r} 
Model & R & R Square & $\begin{array}{c}\text { Adjusted R } \\
\text { Square }\end{array}$ & $\begin{array}{c}\text { Std. Error of the } \\
\text { Estimate }\end{array}$ \\
\hline 1 & $.281^{\mathrm{a}}$ & .079 & .051 & \\
\hline
\end{tabular}

a. Predictors: (Constant), x5, x4, x1, x3, x2

b. Dependent Variable: y

Dari tabel berikut diperoleh $\mathrm{R}$ square sebesat 0.281, dengan demikian dapat disimpulkan bahwa konten pemasaran berpengaruh terhadap keputusan pembelian sebesar $28,1 \%$ sementara 71,9\%\% lainnya dipengaruhi oleh variabel lain diluar penelitian ini.

\section{CONCLUSION AND SUGESTION}

Shopee sudah melakukan konten pemasaran dengan mengacu pada indikatorindikator sebagai berikut : desain, berita terkini, pengalaman saat membaca, waktu penayangan da nisi berita. Keputusan pembelian yang dilakukan pelanggan Shopee menunjukan nilai yang tinggi dilihat dari jumlah peredaran pembelian di Shopee yang mencapai angka 54T di kuartal pertama tahun 2019.

Hasil Uji diperoleh $\mathrm{R}$ square sebesat 0.281, dengan demikian dapat disimpulkan bahwa konten pemasaran berpengaruh terhadap keputusan pembelian sebesar 28,1\% sementara 71,9\%\% lainnya dipengaruhi oleh variabel lain diluar penelitian ini.

Shopee mengalami hambatan berupa isi berita yang kadang tidak sesuai dengan apa yang ingin diutarakan oleh penjual yang bergabung di Shopee. Untuk mengatasi hal tersebut Shopee sudah mengadakan pertemuan dengan para penjual dan memberikan edukasi mulai dari membuat foto yang baik, pencahayaan pada saat membuat foto, copy writing yag baik dan menarik minat beli sehingga lahir keputusan pembelian.

Untuk Shopee sendiri menghadirkan Konten Pemasaran perlu mengacu pada kelima indikator tersebut sehingga semakin banyak orang yang mengunjungi website Shopee. 


\section{REFERENCE}

Ahmad, N. S., Musa, R., \& Harun, M. H. M. (2016). The Impact of Social Media Content Marketing (SMCM) towards Brand Health. Procedia Economics and Finance, 37(16), 331-336.

Alagöz, S. B., \& Ekici, N. (2016). The new phenomenon of the marketing world in the digital era: content marketing. International Journal of Economics, Commerce and Management, 4(12), 639-646.

Chan, A., \& Astari, D. (2017). The Analysis of Content Marketing in Online Fashion Shops in Indonesia. Review of Integrative Business and Economics Research, 6(2), 225.

Glucksman, M. (2008). A Case Study of Lucie Fink I . Introduction II. The Rise of Social Media Influencer Marketing on Lifestyle Branding, 77-87.

Kom, J. M. (2018). Pengaruh content marketing terhadap pembentukan brand awareness pada Kalbis Institute. (2), 45-57.

Limandono, J. A. D. D. (2018). Pengaruh Content Marketing Dan Event Marketing Terhadap Customer Engagement Dengan Sosial Media Marketing Sebagai Variabel Moderasi Di Pakuwon City. Jurnal Strategi Pemasaran, 5(1), 11.

Limani, K. (2018). BRanding with content. (May).

Oktini, P. P. R. T. D. R. (2016). Pengaruh Content Marketing Terhadap Minat Beli Konsumen ( Survei pada Konsumen Thirteenth Shoes Bandung ). Prosiding Manajemen, 116-121.

Saveria, R. A. (2016). Analisis Digital Marketing Dalam Strategi Integrated Marketing Communication Kampanye Politik (Studi Kasus Komunitas Teman Ahok).

Wijayanti, E. (n.d.). Model Social Media Content Marketing untuk Pengrajin di Kota Kudus. (0291), 33-43. 